\title{
Complete streets state laws \& provisions: An analysis of legislative content and the state policy landscape, 1972-2018
}

\author{
Jamila M. Porter \\ Safe States Alliance \\ jamila.porter@safestates.org \\ Joel M. Lee \\ The University of Georgia \\ joellee@uga.edu \\ Marsha Davis \\ The University of Georgia \\ davism@uga.edu
}

\author{
Shenée J. Bryan \\ Research and Evaluation Group \\ sbryan@evaluation-group.com \\ Phaedra S. Corso \\ Kennesaw State University \\ pcorso@kennesaw.edu \\ Stephen L. Rathbun \\ The University of Georgia \\ rathbun@uga.edu
}

\begin{abstract}
Across the U.S., states have adopted Complete Streets legislative statutes - state laws that direct transportation agencies to routinely design and operate roadways to provide safe access for all users, including pedestrians, bicyclists, motorists, and public transit users. To date, there has not been a systematic and comprehensive analysis of the content and provisions of these laws. In this study, Complete Streets state statutes were identified using legal research databases. Using established legal mapping methods, a qualitative analysis was conducted of state laws that were effective through December 2018. A codebook and opensource data set were developed to support the public use of the data. Eighteen states and Washington, DC, have adopted Complete Streets legislative statutes. A total of 21 have been adopted, with $76 \%(n=16)$ of laws adopted since 2007. While the laws vary in content, detail, and specificity, several common provisions were identified across statutes. Complete Streets legislative statutes may be essential to ensure that road networks throughout states are safe, connected, and accessible for all users. This study provides key insights into the legislative landscape of Complete Streets state laws and makes available a new data set that can support future evaluations of these laws.
\end{abstract}

\section{Article history:}

Received: January 3, 2019

Received in revised form:

June 14, 2019

Accepted: June 24, 2019

Available online: July 25, 2019

\section{Introduction}

Pedestrian and bicycle injuries resulting from collisions with motor vehicles have long been significant public health and transportation safety problems in the U.S. Each year throughout the nation, an average of nearly 5,000 pedestrians and over 700 bicyclists are fatally injured in collisions with motor vehicles, and tens of thousands more are non-fatally injured (National Highway Traffic Safety Administration, 2017). Pedestrian and bicyclist deaths have increased substantially in the last decade to comprise

Copyright 2019 Jamila M. Porter, Shenée J. Bryan, Joel M. Lee, Phaedra S. Corso, Marsha Davis, \& Stephen L. Rathbun http://dx.doi.org/10.5198/jtlu.2019.1512

ISSN: 1938-7849 | Licensed under the Creative Commons Attribution - Noncommercial License 4.0

The Journal of Transport and Land Use is the official journal of the World Society for Transport and Land Use (WSTLUR) and is published and sponsored by the University of Minnesota Center for Transportation Studies. 
$20 \%$ of all U.S. traffic fatalities, resulting in the death of nearly one pedestrian every two hours and one bicyclist every twelve hours (National Highway Traffic Safety Administration, 2017).

Throughout the 20th century, laws adopted in the U.S. related to transportation, taxes, housing, and zoning collectively resulted in the prioritization of the automobile as the nation's primary mode of transportation. The 1956 Interstate Highway Act - funded by fuel taxes - led to the construction of a 41,000 mile interstate highway system developed specifically to "provide for the expected growth of motor vehicle traffic" (Eisenhower, 1956, p. 180). Federal housing policies adopted as early as the 1920s incentivized buyers to purchase new single family homes outside of the urban core (Emerson, 2008), which were in areas that could only be efficiently accessed by automobile. Zoning laws - which legislate land sizes, uses, and development in specific geographic areas - have generally focused on perpetuating low-density growth patterns and auto-centric sprawl (Jewitt, 2016). As a result, U.S. roadways have been principally constructed to accommodate motor vehicles above and beyond all other modes of transportation. This "auto-normative paradigm" of transportation planning in the U.S. has contributed to automobile dependency, suburban sprawl, and ultimately, increased injurious interactions between motor vehicles, pedestrians, and bicyclists (Buehler, 2014; Zavestoski \& Agyeman, 2015, p. 1).

After decades of increasing injury rates, efforts to improve pedestrian and bicycle safety in the U.S. through built environment policy began to coalesce in the 1970s. The Federal-Aid Highway Act of 1973 provided states and communities with more discretion over their transportation infrastructure, thus opening the door for initial investments in active transportation projects (Fields \& Cradock, 2014). Several community groups, advocates, and state and local governments began to promote "routine accommodation" policies, which encouraged or required transportation agencies to accommodate pedestrians and bicyclists with appropriate facilities (e.g., sidewalks, protected bike paths, pedestrian refuge islands, etc.) as a routine part of their roadway planning, design, construction, operation, and maintenance activities (Chicago Metropolitan Agency for Planning, 2015; Contra Costa Transportation Authority, 2015; Geraghty et al., 2009; Handy \& McCann, 2011). Although meaningful to transportation practitioners and advocates, routine accommodation was not a term that was commonly known by policymakers or the public. Eventually, an alternate term - Complete Streets - was introduced in 2003 (McCann, 2013). The terms routine accommodation and Complete Streets began to be used interchangeably, and the U.S. Federal Highway Administration (FHWA) refers to both terms synonymously (Federal Highway Administration, 2015). By adopting a Complete Streets policy, states and local jurisdictions can direct "transportation planners and engineers to routinely design and operate the entire right of way to enable safe access for all users, regardless of age, ability, or mode of transportation" (National Complete Streets Coalition \& Smart Growth America, 2018c, p. 1); ultimately, "pedestrians, bicyclists, motorists and transit riders of all ages and abilities must be able to safely move along and across a complete street" (McCann, 2013, p. 26).

As of December 2018, over 1300 state, regional, and local governments have adopted Complete Streets policies, totaling more than 1400 policies nationwide (National Complete Streets Coalition \& Smart Growth America, 2018b). Complete Streets policies have been adopted in a variety of forms, including comprehensive plans, design manuals, departmental policies, resolutions, executive orders, and laws (National Complete Streets Coalition \& Smart Growth America, 2018a). Despite the variety of policy types that exist, adopting Complete Streets legislation at the state level has been considered essential to create statewide transportation networks that give people the choices and access they need. This is due to the fact that "states control many community roadways and often set the standard for streets in cities and counties" (AARP, Seskin, \& McCann, 2013, p. 3). Although the degree of influence that state laws have over road design varies by state, legislative action at the state level can be critical to ensure that state transportation agencies make a long-term, statewide commitment to road safety for pedestrians, bicyclists, and other non-motorized road users. 
As Complete Streets policies have been increasingly adopted, these policies and their potential impacts have been assessed from a variety of perspectives. As transportation professionals, Carter et al. (2013) explored the effect of specific transportation system elements (e.g., posted speed limits, number of vehicle lanes, lane width, parking occupancy, etc.) on levels of service for key modes impacted by Complete Streets, including pedestrians, bicyclists, transit users, and automobiles. Economists Vandegrift and Zanoni (2018) assessed the impact of Complete Streets policy adoption on amenity value for local residents using house prices. Keippel et al. (2017) described collaborative efforts between health care and public health partners in Billings, Montana who used a gender equity-infused process to adopt a local Complete Streets policy. Moreland-Russell, Eyler, Barbero, Hipp, and Walsh (2013) used social science and public health theory to confirm several predictors of community-level Complete Streets policy adoption, including state obesity rates and the number of active commuters in the state. MacLeod, Sanders, Griffin, Cooper, and Ragland (2018) combined perspectives from public health, planning, and engineering to explore the typologies of intersections within a five-mile segment of Los Angeles, CA including intersections with Complete Streets-related pedestrian features - and examine their impact on pedestrian injuries and fatalities. Furthermore, we utilized a public health perspective to evaluate Florida's 1984 Complete Streets state law and its impact on pedestrian fatalities across the state (Porter et al., 2018).

Although state laws now known as Complete Streets legislative statutes have been enacted since the early 1970s, very little is known of their content or legal provisions. Organizations such as the National Complete Streets Coalition and the National Conference of State Legislators have monitored the adoption of state and local Complete Streets policies (National Complete Streets Coalition \& Smart Growth America, 2018a; National Conference of State Legislatures, 2018). However, to date there has not been a rigorous analysis of these policies that can be defined as policy surveillance: the "ongoing, systematic collection, analysis, interpretation, and dissemination of information about a given body of public health law and policy" (Chriqui, O'Connor, \& Chaloupka, 2011, p. 21). This paper focuses on Complete Streets policy surveillance and makes two key contributions to advance public health, transportation, and legal research in this area: (1) It assesses the current landscape of Complete Streets laws that have been adopted by state legislatures in the United States; and (2) It describes the first open-source data set of Complete Streets state laws that can be used to support future policy evaluation research. Our systematic and comprehensive analysis of state Complete Streets laws is an initial step toward helping policymakers, practitioners, and researchers better understand the content, features, and provisions of these laws and to ultimately enhance their utility, implementation, and impact.

\section{$2 \quad$ Methods}

Informed by established legal mapping methods (Burris, 2018; Harvey, 2013; Ibrahim, Anderson, Burris, \& Wagenaar, 2011), a systematic qualitative analysis was conducted of Complete Streets legislative statutes made effective between January 1972 and December 2018. LexisNexis Academic and Fastcase legal research databases were used to search for and obtain full statute texts across all 50 states and Washington, DC. The search terms that were used included: "complete streets," "pedestrian facilities," "pedestrian accommodation," "pedestrian and bicycle," "pedestrian or bicycle," "road construction," and "routine accommodation." To validate and inform the search results, comparisons were made between the laws obtained through the two databases and a publicly available list of known state Complete Streets statutes that have been documented by the AARP et al. and the National Complete Streets Coalition (AARP et al., 2013; National Complete Streets Coalition \& Smart Growth America, 2018a). In cases where only a citation or act number was available in either database, websites of state legislatures were visited to obtain the full statute texts. 
After reviewing the text of each statute, a list of variables were developed and defined to systematically code the statute texts. Variables were informed by the text of the laws themselves, as well as policy elements developed by the National Complete Streets Coalition to describe a comprehensive Complete Streets policy (National Complete Streets Coalition \& Smart Growth America, 2012). To ensure familiarity with legal terminology, two law students coded each of the statutes. An initial list of variables and definitions was reviewed and refined by the coders and supervising researcher through an iterative process. Laws were coded for a total of 35 variables within 16 discrete categories, including road user types, roadway development and maintenance activities referenced, and provisions related to design standards, exceptions, and funding allocations (Table 1). 
Table 1. Variables coded in the Complete Streets state law data set: Categories, definitions, and number of related variables

\begin{tabular}{|c|c|c|}
\hline Category & Definition & $\begin{array}{c}\text { Number of } \\
\text { Related Variables }\end{array}$ \\
\hline Statute Adopted & The state adopted or did not adopt a Complete Streets statute & 1 \\
\hline Date Effective $^{\star}$ & Date on which the law was scheduled to take effect & 1 \\
\hline $\begin{array}{l}\text { References "Health" } \\
\text { and "Safety" }\end{array}$ & $\begin{array}{l}\text { Provision that states a purpose of the law is to address "health" } \\
\text { and/or "safety" }\end{array}$ & 2 \\
\hline $\begin{array}{l}\text { References "All } \\
\text { Transportation Projects" }\end{array}$ & $\begin{array}{l}\text { Provision that states that the law applies to "all transportation } \\
\text { projects" related to roadways that are undertaken within the } \\
\text { state }\end{array}$ & 1 \\
\hline References "All Users" & $\begin{array}{l}\text { Provision that states that the law applies to "all users" of the } \\
\text { transportation system }\end{array}$ & 1 \\
\hline Road User Types & $\begin{array}{l}\text { Road users that the statute explicitly references that should } \\
\text { be accommodated }\end{array}$ & 8 \\
\hline Network Connectivity & $\begin{array}{l}\text { Provisions that state or indicate that a purpose of the law is to } \\
\text { create interconnected and/or integrated road networks that } \\
\text { accommodate non-motorized travel }\end{array}$ & 1 \\
\hline $\begin{array}{l}\text { Roadway Development } \\
\text { and Maintenance Activi- } \\
\text { ties }\end{array}$ & $\begin{array}{l}\text { Provisions that explicitly state to which road development } \\
\text { and maintenance activities the law applies }\end{array}$ & 7 \\
\hline Design Standards & $\begin{array}{l}\text { Provisions that reference specific design manuals, criteria, } \\
\text { guidelines, or standards }\end{array}$ & 2 \\
\hline Performance Standards & $\begin{array}{l}\text { Provisions that refer to the development of performance } \\
\text { standards with measurable outcomes }\end{array}$ & 1 \\
\hline Local Plans & $\begin{array}{l}\text { Provisions that state that city and/or county general plans } \\
\text { must include elements that address accommodations for } \\
\text { non-motorized users }\end{array}$ & 1 \\
\hline $\begin{array}{l}\text { Modifications to } \\
\text { Support Implementation }\end{array}$ & $\begin{array}{l}\text { Provisions that encourage or mandate modifications to pro- } \\
\text { cedures, guidelines, or plans to support the implementation } \\
\text { of the statute }\end{array}$ & 1 \\
\hline Advisory Board & $\begin{array}{l}\text { Provision that establishes an Advisory Board to support the } \\
\text { development of procedures and guidance to support multi- } \\
\text { modal planning and design }\end{array}$ & 1 \\
\hline Exceptions & Provisions that describe specific exceptions to the law & 4 \\
\hline Funding Allocation & $\begin{array}{l}\text { Provisions that refer to specific funding allocations that } \\
\text { should be used to support non-motorized transportation fa- } \\
\text { cilities }\end{array}$ & 1 \\
\hline $\begin{array}{l}\text { Application to State and/ } \\
\text { or Federally Funded } \\
\text { Roads }\end{array}$ & $\begin{array}{l}\text { Provisions that explicitly state that the law applies to state } \\
\text { and/or federally funded roads }\end{array}$ & 2 \\
\hline \multicolumn{2}{|l|}{ Total } & 35 \\
\hline
\end{tabular}

*"Effective dates are either specified in the statute text or are governed by default rules that specify the effective dates of newly signed state laws, which vary by state. 
Each student coded the laws for all variables separately, blinded to the other's results. To calculate interrater reliability, half of the coded statutes were randomly selected using the random number generator in Microsoft Excel. Interrater agreement was calculated to be very high at $0.92(\kappa=0.84)$, indicating strong interrater reliability (McHugh, 2012). Divergences were reviewed by the supervising researcher and both coders; through several discussions, the divergences were ultimately resolved within the data set. Upon completing the coding process, the codebook was finalized to include variable names, definitions, values, labels, and notes. The full data set, codebook, and decision rules are available on Mendeley (https://data.mendeley.com/datasets).

\section{$3 \quad$ Results}

As of December 2018, 18 states and Washington, DC, had collectively adopted a total of 21 laws* that could be categorized as Complete Streets legislative statutes. Findings for all state laws identified by the study were summarized temporally, contextualized by historic events associated with the adoption of state Complete Streets laws in the U.S. (Figure 1).

\footnotetext{
* Maryland and Rhode Island each adopted a second Complete Streets state law to address perceived gaps in the original versions of their laws. Figure 1 notes the states' rationale for the adoption of these additional laws.
} 


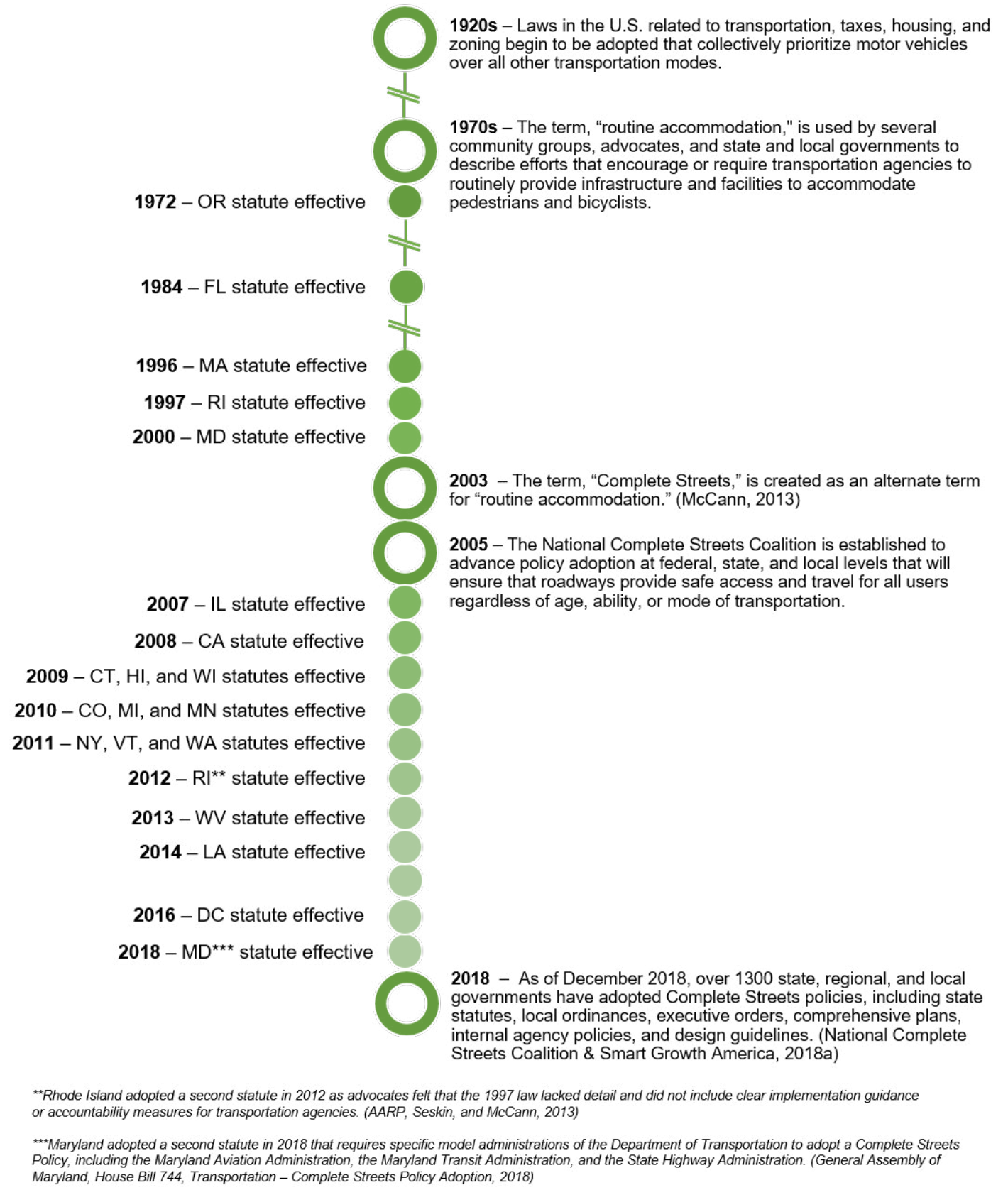

Figure 1. Historic timeline: Complete Streets state laws made effective and related events associated with state Complete Streets law adoption in the U.S., 1920s - 2018

Although the oldest state law - Oregon - was enacted in 1971 and made effective on January 1, 1972 , over $76 \%(\mathrm{n}=16)$ of Complete Streets state statutes have only been adopted since 2007. Prior to the year 2000, only five states had adopted what were once solely known as routine accommodation laws. Of these five states, two were located in the South Census region, two were located in the Northeast Census region, and one was located the Western Census region. However, policy adoption began to pick up later in the decade, between 2007 and 2014, at least one law was adopted by a state legislature each year, including the first statutes to be adopted in the Midwest (Illinois in 2007 and Wisconsin in 
2009). Over $40 \%$ of all state statutes were adopted in a three-year period from $2009-2011$, indicating particular interest and action in this policy area by state legislatures during that timeframe. By 2014, multiple states in each of the four U.S. Census regions had adopted Complete Streets statutes: five states each in the Western and Northeastern regions and four states each in the Midwestern and Southern regions.

As part of our analysis, we highlighted four common provisions across statutes that may be of legal, political, and research interest due to their potential connections to policy implementation (Table 2). These provisions - displayed in a geospatial distribution of all Complete Streets state laws (Figure 2) include those that: (1) encourage or require the accommodation of pedestrians and bicyclists in local plans; (2) indicate whether or not the law applies to state and federally-funded roads; (3) reference specific funding allocations to support the construction and maintenance of accommodations for pedestrians and bicyclists; and (4) refer to network connectivity as an explicit purpose of the statute. These four provisions were specifically highlighted due to their connections to the funding, feasibility, and use of Complete Streets-related infrastructure - topics that have previously been of key interest to government agencies, lawmakers, and constituents (Dodson et al., 2014; Heinrich, Aki, Hansen-Smith, Fenton, \& Maddock, 2011). Metropolitan planning organizations (MPOs) and local governments often have primary responsibility for funding and implementing pedestrian and bicycle planning projects, including those associated with Complete Streets policies (Handy \& McCann, 2011). As such, laws that require the accommodation of pedestrians and bicyclists in local plans and include specific funding allocations to support these accommodations could help ensure that they are implemented by MPOs and local government agencies. In keeping, a provision that specifies its applicability to both state and federallyfunded roads may help ensure that the law is applied to all roads within the network, whether they are constructed and maintained using state tax dollars or through federal funding programs. Finally, the provision related to network connectivity was highlighted due to the importance of interconnectivity between disparate pedestrian and bicycle accommodations along roadways. These interconnections are essential to ensure that street networks are efficient and practical for users. However, none of the Complete Streets legislative statutes in this analysis were found to include all four provisions; furthermore, four statutes did not include any of these provisions (Colorado, Illinois, Massachusetts, and Rhode Island). 
Table 2. Four common provisions of Complete Streets state statutes with potential connections to policy implementation, January 1972-December 2018

\begin{tabular}{|c|c|c|c|c|c|}
\hline State & $\begin{array}{c}\text { Statute } \\
\text { Effective } \\
\text { Date* }^{*}\end{array}$ & $\begin{array}{c}\text { Encourages or } \\
\text { Requires } \\
\text { Non-Motorized } \\
\text { Accommodations } \\
\text { in Local Plans } \\
\end{array}$ & $\begin{array}{l}\text { Applies to State } \\
\text { and Federally- } \\
\text { Funded Roads }\end{array}$ & $\begin{array}{c}\text { Refers to a } \\
\text { Specific Funding } \\
\text { Allocation for } \\
\text { Non-Motorized } \\
\text { Accommodations }\end{array}$ & $\begin{array}{l}\text { Refers to Network } \\
\text { Connectivity as } \\
\text { an Intent of the } \\
\text { Statute }\end{array}$ \\
\hline $\mathrm{CA}$ & $9 / 30 / 2008$ & $x$ & & & $x$ \\
\hline $\mathrm{CO}$ & $7 / 1 / 2010$ & & & & \\
\hline $\mathrm{CT}$ & $7 / 1 / 2009$ & & $x$ & $x$ & \\
\hline $\mathrm{DC}$ & $7 / 25 / 2016$ & & & & $x$ \\
\hline FL & $10 / 1 / 1984$ & $x$ & & $x$ & $x$ \\
\hline $\mathrm{HI}$ & $5 / 6 / 2009$ & $x$ & & & \\
\hline $\mathrm{IL}$ & $7 / 1 / 2007$ & & & & \\
\hline LA & $6 / 4 / 2014$ & & & & $x$ \\
\hline MA & $8 / 18 / 1996$ & & & & \\
\hline $\mathrm{MD}$ & $5 / 18 / 2000$ & & & $x$ & $x$ \\
\hline $\mathrm{MD}$ & 7/1/2018 & & & & $x$ \\
\hline MI & $8 / 1 / 2010$ & $x$ & & $x$ & $x$ \\
\hline $\mathrm{MN}$ & $8 / 1 / 2010$ & $x$ & & & \\
\hline NY & $2 / 11 / 2012$ & & $x$ & & \\
\hline OR & $1 / 1 / 1972$ & $x$ & & $x$ & \\
\hline RI & 7/2/1997 & & & & \\
\hline $\mathrm{RI}$ & $6 / 11 / 2012$ & & $x$ & & \\
\hline VT & 7/1/2011 & $x$ & & & $x$ \\
\hline WA & $7 / 22 / 2011$ & $x$ & & $x$ & \\
\hline WI & $6 / 30 / 2009$ & & $x$ & & \\
\hline WV & $7 / 9 / 2013$ & $x$ & $x$ & & $\mathbf{x}$ \\
\hline
\end{tabular}

- Local Planning: Many localities have developed general or comprehensive plans that serve as guides for making local land-use and zoning decisions. These plans inform the rate, timing, and location of future growth (Georgia Institute of Technology, 2016). Complete Streets statutes can explicitly include provisions that encourage or require local governments to provide accommodations for pedestrians and bicyclists. When implemented, these provisions can help ensure better coordination and cooperation between state and local transportation and public works agencies as they collectively address the needs of non-motorized road users. Nine states and Washington, DC $-48 \%$ of laws $(n=10)$ - currently require that local general plans include elements that address accommodations for pedestrians, bicyclists, and other non-motorized road users.

- Application to State and Federally-Funded Roads: Given that Complete Streets laws may require significant changes to road infrastructure across jurisdictions, a statute may include provisions that clarify its application to both state and federally-funded roads. To have maximal reach and applicability, a Complete Streets state law should apply to all roads within a state, regardless 
of where they are located within the road network or what agencies have jurisdiction over their construction and maintenance. A total of five laws (24\%) include provisions which specify that their Complete Streets statute applies to both state and federally-funded roads.

- Funding Allocations: A provision that requires a minimum funding allocation for pedestrian and bicycle accommodations can ensure that some state funding is regularly allotted to support these efforts, and can also prevent the law from becoming an unfunded mandate. Six states nearly $30 \%$ of all laws - include provisions that refer to how funding should be allocated to support transportation facilities for non-motorized road users.

- Network Connectivity: As noted by Zavestoski and Agyeman (2015, p. 7), streets are "significant social and symbolic spaces where users are linked to intersecting economic, transportation, food, cultural, and governance systems." However, in practice, many engineering projects intended to accommodate pedestrians and bicyclists result in disconnected facilities that span only a few blocks. Larger infrastructural projects may not consistently span an entire neighborhood or district. Without network connectivity, non-motorized road users - pedestrians in particular - may be unable to fully benefit from well-intentioned facilities that simply do not provide safe, continuous, and interconnected pathways to goods and services. Of the 21 Complete Streets legislative statutes identified by this analysis, nine laws (43\%) refer to network connectivity as an intent of the law. 


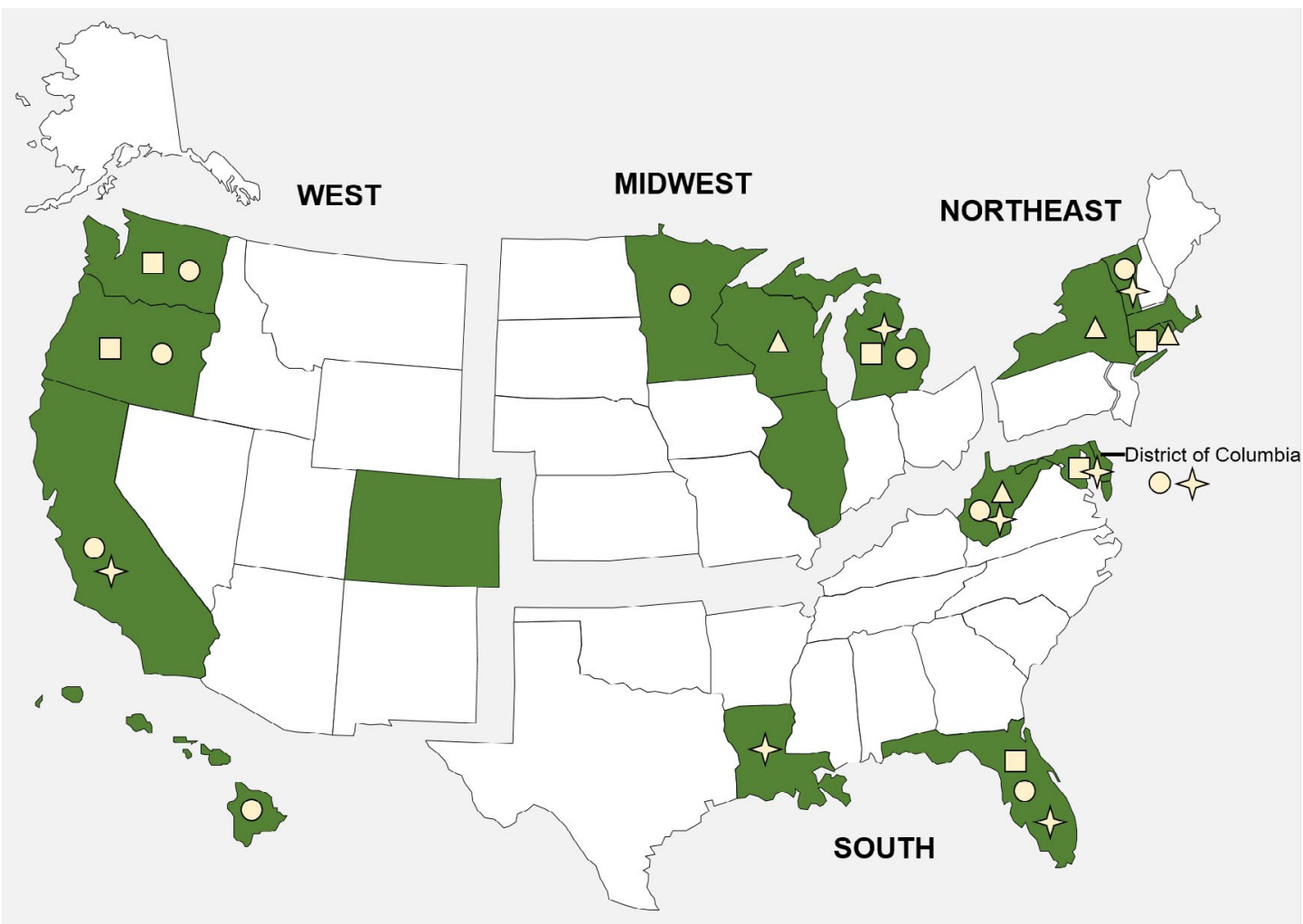

Adopted a Complete Streets Legislative Statute

Encourages or Requires Non-Motorized Accommodations in Local Plans

$\triangle$ Applies to State and Federally-Funded Roads

$\square$ Refers to a Specific Funding Allocation for Non-Motorized Accommodations

$\&$ Refers to Network Connectivity as an Intent of the Statute

Figure 2. Geospatial distribution of state Complete Streets statutes and common provisions with potential connections to policy implementation, January 1972 - December 2018

\section{Discussion}

Our study builds on previous research related to the prevalence and diffusion of Complete Streets policy adoption (Carlson et al., 2017; Moreland-Russell et al., 2013) by conducting a systematic inventory and analysis of Complete Streets laws that have been adopted by state legislatures. Our study found that over one-third of U.S. states and Washington, DC, have adopted a Complete Streets legislative statute across all four U.S. Census regions. While these laws vary in approach and specificity, the laws were coded for a total of 35 variables across 16 categories of provisions. Four common provisions were highlighted due to their potential connections to policy implementation. Despite the sheer volume of Complete Streets policies that have been adopted, this is the first study to date that has utilized a systematic approach to assess the specific elements and provisions of Complete Streets state laws. While many more local and regional-level Complete Streets policies have been adopted, we looked specifically at state legislation 
given the potential wide-ranging impacts of these laws. State statutes can have significant influence over policies that are adopted and implemented at local and regional levels; state transportation laws in particular can impact the design, structure, and functionality of statewide road networks, even those under the jurisdiction of local transportation authorities.

Although the first routine accommodation statute was made effective in 1972, only four additional statutes were adopted in the subsequent three decades. However, once the term, "Complete Streets," was coined in 2003, it helped spark the U.S. "Complete Streets movement": a "broad coalition of bicycle riders, transportation practitioners, public health leaders, older Americans, smart growth advocates, real estate agents, and more" that worked collectively to "build streets that are safe for everyone" (McCann, 2013, p. 2). This coalition - officially known by 2005 as the National Complete Streets Coalition prompted renewed momentum behind the adoption of state and local Complete Streets policies. Prior to the existence of the National Complete Streets Coalition, the adoption of policies related to routine accommodation had been relatively sluggish. However, following the establishment of the Coalition, efforts to get Complete Streets policies enacted by governments intensified. Increased citizen participation in transportation planning processes and enhanced advocacy for an "improved quality of life-centered transportation system" resulted in an uptick in the adoption of a variety of Complete Streets policies (Fields \& Cradock, 2014, p. 326). The Complete Streets movement has also been bolstered by demographic trends: national surveys have revealed that Americans are largely supportive of communities that are designed for safe walking and biking (Fairbank Maslin Maullin Metz \& Associates and Public Opinion Strategies, 2012; Weigel \& Metz, 2010). Additionally, the baby boom generation - one of the largest generations in history - will require pedestrian-friendly streets and public transportation options as they age in order to travel safely and independently within and beyond their residential communities (Transportation for America, 2011).

While policymakers and practitioners have found that adopting Complete Streets laws can be relatively straightforward, they have found that effectively implementing these laws can be much more challenging (Schmitt, 2013). Implementation can be particularly difficult when a policy requires the interpretation and application of potentially vague language, cooperation across a variety of agencies and jurisdictions, and significant changes to entrenched processes and systems. Understanding how and to what extent specific provisions are being implemented as intended and identifying specific factors that can make policy implementation easier or more difficult are important areas of future research. Additionally, the adoption of Complete Streets legislation is only one of several state policy approaches that may be utilized to enhance the safety of pedestrians and bicyclists. Many other well-known policy approaches attempt to regulate the behavior of motorists (e.g., speeding laws, driver education policies, etc.). Determining how these laws interact with Complete Streets policies to impact pedestrian and bicycle safety is a further area of potential research.

It is also important to note that laws are not enacted and implemented in a vacuum; the connections between Complete Streets policies and other socioeconomic forces, political contexts, and legal circumstances should also be investigated, as well as their impacts on issues related to equity and social justice. Laws can only be strengthened and enhanced by understanding that success does not stop at policy adoption; rather, laws must be kept relevant and effective based on findings from policy evaluations that investigate their implementation and impact. More research is also needed to understand how Complete Streets laws may impact specific health outcomes and to determine if specific provisions can be linked to policy effectiveness. Understanding the specific features and elements of Complete Streets laws is a critical first step in determining how the adoption and implementation of these policies may be connected to important health and transportation safety outcomes. 
Claims that Complete Streets policies improve pedestrian safety, increase physical activity levels, decrease motor vehicle crashes, and reduce obesity have been promoted by a variety of federal agencies and professional organizations in the U.S., including the FHWA, the Centers for Disease Control and Prevention (CDC), the American Planning Association (APA), and the American Society of Civil Engineers (ASCE) (American Planning Association, 2015; American Society of Civil Engineers, 2011; Khan et al., 2009; Smith, Reed, \& Baker, 2010). However, these claims have only been based on evaluations of specific pedestrian and bicycle facilities, such as raised medians, signalized intersections, sidewalks, and pedestrian overpasses (Campbell, Zegeer, Huang, \& Cynecki, 2004; King, Carnegie, \& Ewing, 2003; Retting, Ferguson, \& McCartt, 2003). True tests of these claims require thorough evaluations of Complete Streets policies, including potential impacts of their adoption, provisions, and implementation processes. However, evaluations of Complete Streets policies are exceptionally limited, particularly with regard to their direct impacts on specific public health outcomes. Our evaluation of Florida's 1984 Complete Streets state law confirmed that the law was associated with a 29-year decrease in pedestrian deaths statewide, saving more than 3500 lives over that period (Porter et al., 2018). Several provisions of Florida's Complete Streets statute may have contributed to this outcome: the law states that the accommodation of pedestrians and bicyclists should be included in all state, regional, and local transportation plans. The law also refers to specific funding allocations that can be used to support pedestrian and bicycle facilities and interconnected street networks, as the state department of transportation is directed "to support a statewide system of interconnected multiuse trails and to pay the costs of planning, land acquisition, design, and construction of such trails and related facilities" ("Florida Statute $\$ 335.065$ Bicycle and Pedestrian Ways Along State Roads and Transportation Facilities," 1984, p. 2).

Despite these promising findings, recent increases in pedestrian and bicycle fatalities nationwide indicate that significant systemic, comprehensive, and long-term changes will be necessary to reduce these deaths. In addition to the adoption and implementation of Complete Streets policies, advances and improvements are needed in other complemental strategies, including land-use and zoning policies, community design practices, driver education and licensing, mass transit accessibility, traffic law enforcement, and transportation technology (Buehler \& Pucher, 2017; Schneider, 2018). Potential connections between these strategies, Complete Streets policies, and public health outcomes can be identified and confirmed through further evaluation research.

\section{$5 \quad$ Limitations}

As with any study involving qualitative research, the analysis of legal texts is inherently subject to interpretability. However, a set of decision rules were included with the codebook to ensure that coders' interpretations of specific policy provisions were clearly documented for future users of the data set. Additionally, the data set includes an analysis of the statute text as enacted; as a result, this inventory can be used by practitioners, researchers, and policymakers to identify specific policy elements and assess variations in these laws across states. However, given the lack of information regarding how and to what extent laws are being implemented across states, this study cannot draw conclusions regarding the quality or efficacy of specific state laws.

\section{Conclusions}

This study contributes to current efforts to better understand the Complete Streets legal landscape by describing the current status of Complete Streets state laws. At the time of this study, 18 U.S. states and Washington, DC, collectively adopted a total of 21 Complete Streets statutes. Although the laws vary by the type and number of provisions included, there are 16 discrete categories that were coded across 
all laws. Four common provisions were investigated in more detail due to their potential connections to policy implementation and interest to lawmakers, constituents, and practitioners: $48 \%$ of laws ( $\mathrm{n}=10)$ include provisions that encourage or require the accommodation of non-motorized users in local plans; $24 \%$ of laws $(n=5)$ explicitly apply to both state and federally-funded roads; $28 \%$ of laws $(n=6)$ describe specific funding allocations that are to be used for pedestrian and bicycle accommodations along roadways; and $43 \%$ of laws $(n=9)$ refer to network connectivity as an intent of the law.

Our study contributes to future evaluations of Complete Streets state laws by creating a comprehensive, open-source data set that describes specific policy elements and provisions across laws. This data set can be used by researchers, policymakers, and other stakeholders to further evaluate Complete Streets state laws by examining specific policy features, analyzing variations in statute texts across states, testing provisions to identify implementation gaps, and determining how to further strengthen current and future laws.

\section{Acknowledgements}

The authors sincerely thank those that provided invaluable assistance and support of this research, including: Barry Porter, Jr., JD; Kerri Lowrey, JD, MPH; Kathleen Hoke, JD; Sophia Jafrul, JD; Austin Roche, JD; and the Network for Public Health Law.

This research did not receive any specific grant from funding agencies in the public, commercial, or not-for-profit sectors. 


\section{References}

AARP, Seskin, S., \& McCann, B. (2013). Complete Streets in the states: A guide to legislative action. Retrieved from http://www.smartgrowthamerica.org/documents/cs/resources/cs-aarp-statelegislationtoolkit.pdf

American Planning Association. (2015). Complete Streets. Retrieved from https://www.planning.org/ research/streets/

American Society of Civil Engineers. (2011). Policy statement: Complete Streets (ASCE policy statement 537). Retrieved from http://www.smartgrowthamerica.org/documents/cs/resources/ASCEPS537.pdf

Buehler, R. (2014). 9 Reasons the U.S. ended up so much more car-dependent than Europe. CityLab. Retrieved from https://www.citylab.com/transportation/2014/02/9-reasons-us-ended-so-muchmore-car-dependent-europe/8226/

Buehler, R., \& Pucher, J. (2017). Trends in walking and cycling safety: Recent evidence from high-income countries, with a focus on the United States and Germany. American Journal of Public Health, 107(2), 281-287. doi:10.2105/ajph.2016.303546

Burris, S. C. (2018). How to write a legal mapping paper (Research Paper No. 2018-10, 17). Philadelphia: Social Science Research Network, Temple University Legal Studies.

Campbell, B. J., Zegeer, C. V., Huang, H. H., \& Cynecki, M. J. (2004). A review of pedestrian safety research in the U.S. and abroad (FHWA-RD-03-042). Retrieved from https://www.fhwa.dot.gov/ publications/research/safety/pedbike/03042/03042.pdf

Carlson, S. A., Paul, P., Kumar, G., Watson, K. B., Atherton, E., \& Fulton, J. E. (2017). Prevalence of Complete Streets policies in U.S. municipalities. Journal of Transport \& Health, 5, 142-150. doi:10.1016/j.jth.2016.11.003

Carter, P., Martin, F., Núñez, M., Peters, S., Raykin, L., Salinas, J., \& Milam, R. (2013). Complete enough for Complete Streets? Sensitivity testing of multimodal level of service in the highway capacity manual. Transportation Research Record, 2395(1), 31.

Chicago Metropolitan Agency for Planning. (2015). Complete Streets: The basics. Retrieved from https:// www.cmap.illinois.gov/documents/10180/391170/FY15-0082+complete+streets+the+basics.pdf/ e9ad3ad8-6786-4082-9cfa-afacfa26b499

Chriqui, J. F., O'Connor, J. C., \& Chaloupka, F. J. (2011). What gets measured gets changed: Evaluating law and policy for maximal impact. The Journal of Law, Medicine \& Ethics, 39(Supplement 1), 6. doi:10.1111/j.1748-720X.2011.00559.x

Contra Costa Transportation Authority. (2015). Routine accommodation. Retrieved from http://www. ccta.net/_resources/detail/31/1

Dodson, E. A., Langston, M., Cardick, L. C., Johnson, N., Clayton, P., \& Brownson, R. C. (2014). Everyone should be able to choose how they get around: How Topeka, Kansas, passed a Complete Streets resolution. Preventing Chronic Disease, 11, 1.

Eisenhower, D. D. (1956). Annual message transmitting the economic report to the Congress. Washington, DC: Office of the Federal Register. Retrieved from https:/quod.lib.umich.edu/p/ppotpus/472841 3.1956.001?rgn=main;view=fulltext

Emerson, C. D. (2008). All sprawled out: How the federal regulatory system has driven unsustainable growth. Tennessee Law Review, 75(3), 411-451.

Fairbank Maslin Maullin Metz \& Associates and Public Opinion Strategies. (2012). Key findings from the National Survey on Transportation Options. Retrieved from http://docs.nrdc.org/energy/files/ ene_12090401a.pdf 
Federal Highway Administration. (2015, October 27). Tools and practices for land use integration: Roadway design guidelines and standards. Retrieved from http://www.fhwa.dot.gov/planning/processes/land_use/land_use_tools/page04.cfm\#toc380582801

Fields, B., \&Cradock, A.L. (2014). Federal activetransportation policy in transition: From ISTEA to Complete Streets. Public Works Management \& Policy, 19(4), 322-327. doi:10.1177/1087724X14546200

Florida Statute $₫ 335.065$ Bicycle and Pedestrian Ways Along State Roads and Transportation Facilities, Florida Annotated Statutes, 335.065 Stat. (1984).

Georgia Institute of Technology (Ed.). (2016). Built environment and public health clearinghouse: Glossary. Atlanta, GA: Georgia Institute of Technology, School of City and Regional Planning.

Geraghty, A. B., Seifert, W., Preston, T., Holm, C. V., Duarte, T. H., \& Farrar, S. M. (2009). Partnership moves community toward Complete Streets. American Journal of Preventive Medicine, 37(6 Suppl 2), S420-427. doi:10.1016/j.amepre.2009.09.009

Handy, S., \& McCann, B. (2011). The regional response to federal funding for bicycle and pedestrian projects. Journal of the American Planning Association, 77(1), 23-38. doi:10.1080/01944363.2011 .526537

Harvey, H. H. (2013). Reducing traumatic brain injuries in youth sports: Youth sports traumatic brain injury state laws, January 2009 - December 2012. American Journal of Public Health, 103(7), 6. doi:10.2105/AJPH.2012.301107

Heinrich, K. M., Aki, N. N., Hansen-Smith, H., Fenton, M., \& Maddock, J. (2011). A comprehensive multi-level approach for passing safe routes to school and complete streets policies in Hawaii. Journal of Physical Activity \& Health, 8, S135.

Ibrahim, J. K., Anderson, E. D., Burris, S. C., \& Wagenaar, A. C. (2011). State laws restricting driver use of mobile communications devices distracted-driving provisions, 1992-2010. American Journal of Preventive Medicine, 40(6), 659-665. doi:10.1016/j.amepre.2011.02.024

Jewitt, M. G. (2016). Encouraging transportation-oriented development in the United States: A case for utilizing earned-as-of-location credits to promote strategic economic development. William \& Mary Law Review, 57(5), 1949-1984.

Keippel, A. E., Henderson, M. A., Golbeck, A. L., Gallup, T., Duin, D. K., Hayes, S., . . Ciemins, E. L. (2017). Healthy by design: Using a gender focus to influence Complete Streets policy. Women's Health Issues, 27(Suppl 1), S22-S28. doi:10.1016/j.whi.2017.09.005

Khan, L. K., Sobush, K., Keener, D., Goodman, K., Lowry, A., Kakietek, J., \& Zaro, S. (2009). Recommended community strategies and measurements to prevent obesity in the United States. Retrieved from http://www.cdc.gov/mmwr/preview/mmwrhtml/rr5807a1.htm

King, M. R., Carnegie, J. A., \& Ewing, R. (2003). Pedestrian safety through a raised median and redesigned intersections. Transportation Research Record: Journal of the Transportation Research Board, $1828,11$.

MacLeod, K. E., Sanders, R. L., Griffin, A., Cooper, J. F., \& Ragland, D. R. (2018). Latent analysis of Complete Streets and traffic safety along an urban corridor. Journal of Transport \& Health, 8(1), 15.

McCann, B. (2013). Completing our streets: The transition to safe and inclusive transportation networks. Washington, DC: Island Press.

McHugh, M. L. (2012). Interrater reliability: The kappa statistic. Biochemia Medica, 22(3), 7.

Moreland-Russell, S., Eyler, A., Barbero, C., Hipp, J. A., \& Walsh, H. (2013). Diffusion of Complete Streets policies across U.S. communities. Journal of Public Health Management and Practice, 19, S89-S96. doi:10.1097/PHH.0b013e3182849ec2

National Complete Streets Coalition, \& Smart Growth America. (2012). Complete Streets local policy workbook. Retrieved from http://www.smartgrowthamerica.org/documents/cs-local-policy-workbook.pdf 
National Complete Streets Coalition, \& Smart Growth America. (2018a). Complete Streets policies nationwide: Policy inventory and policy atlas. Retrieved from https://smartgrowthamerica.org/program/ national-complete-streets-coalition/policy-development/policy-atlas/

National Complete Streets Coalition, \& Smart Growth America. (2018b). National Complete Streets Coalition. Retrieved from https://smartgrowthamerica.org/program/national-complete-streets-coalition/

National Complete Streets Coalition, \& Smart Growth America. (2018c). What are Complete Streets? Retrieved from https://smartgrowthamerica.org/program/national-complete-streets-coalition/publications/what-are-complete-streets/

National Conference of State Legislatures. (2018). State traffic safety legislation database. Retrieved from http://www.ncsl.org/research/transportation/state-traffic-safety-legislation-database.aspx

National Highway Traffic Safety Administration. (2017). Fatality analysis and reporting system (FARS) data files, 1975-2016. Retrieved from ftp://ftp.nhtsa.dot.gov/fars/

Porter, J. M., Rathbun, S. L., Bryan, S. J., Arseniadis, K., Caldwell, L. P., Corso, P. S., . . Davis, M. (2018). Law accommodating nonmotorized road users and pedestrian fatalities in Florida, 1975 to 2013. American Journal of Public Health, 108(4), 525-531. doi:10.2105/AJPH.2017.304259

Retting, R. A., Ferguson, S. A., \& McCartt, A. T. (2003). A review of evidence-based traffic engineering measures designed to reduce pedestrian-motor vehicle crashes. American Journal of Public Health, 93(9), 1456-1463.

Schmitt, A. (2013). Passing a law is the easy part: The challenge of building Complete Streets. Retrieved from http://usa.streetsblog.org/2013/07/11/passing-a-law-is-the-easy-part-the-challenge-of-building-complete-streets/

Schneider, R. J. (2018). Complete Streets policies and eliminating pedestrian fatalities. American Journal of Public Health, 108(4), 43-433. doi:10.2105/AJPH.2018.304317

Smith, R., Reed, S., \& Baker, S. (2010). Street design: Part 1 - Complete Streets. (FHWA-HRT-10-005). Washington, DC: U.S. Department of Transportation, Federal Highway Administration. Retrieved from http://www.fhwa.dot.gov/publications/publicroads/10julaug/03.cfm

Transportation for America. (2011). Aging in place, stuck without options: Fixing the mobility crisis threatening the baby boom generation. Retrieved from http://t4america.org/docs/SeniorsMobilityCrisis.pdf

Vandegrift, D., \& Zanoni, N. (2018). An economic analysis of complete streets policies. Landscape \& Urban Planning, 171, 88.

Weigel, L., \& Metz, D. (2010). Future of transportation survey. Retrieved from http://www.slideshare. net/t4america/future-of-transportation-poll-summary-032910

Zavestoski, S., \& Agyeman, J. (2015). Complete Streets: What's missing? In S. Zavestoski \& J. Agyeman (Eds.), Incomplete streets: Processes, practices, and possibilities (pp. 1-12). New York: Routledge. 